\title{
Historic “HAUFF” Timber Roofs in Poços de Caldas in Brazil
}

\author{
Leandro Dussarrat Brito ${ }^{1}$, André Luis Christoforo ${ }^{2, *}$, Pedro Gutemberg de Alcântara Segundinho ${ }^{3}$, \\ Francisco Antonio Rocco Lahr ${ }^{4}$, Carlito Calil Junior ${ }^{4}$
}

\author{
${ }^{1}$ Wood and Timber Structures Laboratory (LaMEM), São Carlos Engineering School, São Paulo University - USP, São Carlos, SP, Brazil \\ ${ }^{2}$ Centre for Innovation and Technology in Composites - CIT ${ }^{\mathrm{e}} \mathrm{C}$, Department of Civil Engineering (DECiv), Federal University of São \\ Carlos, São Carlos, Brazil \\ ${ }^{3}$ Department of Forest Sciences, Federal University of Espírito Santo (UFES), Jerônimo Monteiro - ES, Brazil \\ ${ }^{4}$ Department of Structures Engineering (SET), Engineering School of São Carlos (EESC), São Paulo University (USP), São Carlos, Brazil
}

\begin{abstract}
This research presents the assessment of historic structural systems timber roofs type "Hauff" of constructions existing in Poços de Caldas, Minas Gerais, Brazil. The large timber structures originated with the engineering company "Hauff", whose production of timber structures contributed in great measure to the technological advance of the industry of construction engineering with wood in Brazil. Based on photographic by techniques of visual inspection (NDT) and descriptive documentation, this paper offers examples of timber roof structures that constitute most of type "Hauff" roof structural systems, such as, lamellar roof structure, sawn lumber nailed arch, plywood arch, shed truss roof, that were built between the years 40 and 60 in the city at Poços de Caldas in Minas Gerais. The timber structures with "Hauff" were built in various regions of Brazil at that time.
\end{abstract}

Keywords Timber structures, Inspection, Assessment, Intervention, Pathologies, Sustainability

\section{Introduction}

According to a historical survey of the construction and engineering related to the history of type "Hauff" in timber structures, have recently been identified in several locations in the city Poços de Caldas, in Brazil, 12 timber roof structures, medium and large possession with various roof structural systems type "Hauff", still existing, built between the 1940s and 1960s. The major roof structural systems observed are the timber roof structures with lamellar roof structure, warehouses with roof structural system type sawn lumber nailed arch, warehouses with roof structural system type plywood arches composed section, warehouse with shed truss roof, which were built at the time.

Restoring existing structures for reuse of the building is a major trend in the global issue of sustainability [1]. With this attitude you can reduce waste generation and material consumption that would result from the process of constructing a new building at the place of that existing old one.

Considering the lack of studies that provided evidence of the timber roof s tructures type "Hauff", built, and still

* Corresponding author:

alchristoforo@gmail.com (André Luis Christoforo)

Published online at http://journal.sapub.org/ijme

Copyright (C) 2016 Scientific \& Academic Publishing. All Rights Reserved existing in Poços de Caldas, it was observed the need to research a little more on this topic, aiming to identify structural systems adopted at that time.

The specific objective of this study sought to document the lifting of the main timber roof structures, which were built with roof structural systems type "Hauff," still existing in the city of Poços de Caldas in Minas Gerais, Brazil.

\section{Material and Methods}

The methodology used for the theoretical foundation of this study was performed a literature review on the roof structural systems type "Hauff". And for the lifting of existing structures in city Poços de Caldas, technical visits were made, where were photographed by techniques of visual inspection (NDT) outside areas, facades, and whenever possible, internal areas to identify details of roof structural systems, in order to catalog these buildings that still exist.

\section{Brief history of timber structures system type "Hauff" in Brasil}

The Erwin Hauff, founder of the company "Hauff", was born in Vienna, Austria and graduated in civil engineering from the Technical University of Munich in 1920. At the end of World War I, Mr. Hauff moved to Brazil, where he became fascinated in studies of Brazilian forest species upon 
observing the physical characteristics of their wood. He collected samples of a wide variety of species, observing their drying behavior, their defects such as cracking and warping, and their workability. All these observations were based on empirical trials [2]. Hauff's success in the 1920s, 30 s and 40s was due, among other things, to the greater availability of skilled labor which was abundant in those days as a result of foreign immigration, which brought to Brazil a large contingent of individuals of medium level very experienced and highly qualified in carpentry trades, as well as in other general construction tasks. Also, at times, Hauff itself brought over several European technicians to train their workers, who were required to be qualified at a technical or specialized level in one area of carpentry, since the Brazilian labor market was going through a crisis, particularly in the late 40s and 50s. These foreign professionals were, in large part, responsible for training many excellent Brazilian carpenters [2].

Of Hauff company's three phases, the first stood out from the others for the technological innovation in wood structures which the company introduced into construction engineering, with timber truss system, known as "Hauff System". These structures included road bridges, soffit scaffolding, framework scaffolding, antenna towers, false work, roofing frameworks in general, and silos. Structures built according to the "Hauff System", which was characterized by the presence of carved dowel connections and trusses, predominated in the first period of wood roofing projects and works. This initial period, in turn, was also divided into two phases. This division was marked by the type of tiles used in roofing, and the first phase, which occurred between 1925 and 1937, was characterized by the use of French-type fired clay tile roofing [2].

The second phase, which began in 1937, was characterized by the use of fiber cement corrugated roofing panels. The use French tiles required a roof framework composed of slats, rafters and purlins. Structural elements such as arches, rigid frames, trusses, etc. consisted of bars with more robust sections, since this type of roofing was heavier than fiber cement panels. Another important aspect of French tiles is the roof bracing system, which is simpler than the system used for frameworks for supporting fiber cement roofing panels, because clay tiles are not fixed to the roof web and therefore do not transfer the effect of wind suction to the structural elements. During this period, it was also common to use arch structures with two or three hinges and wood or steel ties. The combination of the shape of the arch and the mechanical characteristics of wood in resisting tensile and compressive loads parallel to the fibers resulted in a structural solution that could cope with large spans with the rational use of wood. This structural solution was widely used by Hauff for twenty to thirty meter spans, when the arches were braced and supported on, columns and reinforced concrete beams, or on timber columns [2].

During the second and third phase of "Hauff", according to the demand with the growth of construction in the country, have emerged in the market other manufacturers of timber structures for roofing, which was to highlight the criteria that they have achieved in the domestic market, but also the structural types offered by them [2].

\section{Inspection techniques to assess timber structures}

The wood is an amazing combination that exhibits both strength and durability as a structural material used for roof structures. Nevertheless, from the time it is formed in the tree, wood is subject to deterioration by a variety of agents biotic and abiotic [3, 4, 5, 11]. Damage ranges from relatively minor discolorations caused by fungi or chemicals to more serious decay and insect attack [4].

Timber inspection is a learned process that requires some knowledge of wood pathology, wood technology, and timber engineering [4]. This paper covers the fundamentals of timber roof structure inspection for decay and deterioration; it identifies the agents of deterioration and outlines used inspection methods.

For this, there are the main methods that can be used for inspection and evaluation of timber roofs: types and areas for deterioration; inspection techniques; equipment and tools; NDE tool; performance monitoring.

Nondestructive evaluation is the science of identifying the physical and mechanical properties of materials without altering its end-use capabilities and then using this information to make decisions regarding appropriate applications [6]. Nondestructive evaluation (NDE) technologies have contributed significantly toward detect structural problems.

The main methods that are available for inspecting timber structures, normally do not require sophisticated tools. These methods, which include visual characteristics by visual inspection technique; sounding with hammer; probing test; pick test with mortise chisel; measuring moisture content by moisture meter; and microdrilling by Resistograph, for example, may be used singly or in combination $[3,4,6,7$, $11]$.

However, timber structure inspectors have the difficult task of accurately assessing the condition of an existing structure. They must understand the biotic and abiotic factors associated with wood deterioration as well as the relative rate at which these processes occur in a given environment [4].

The visual inspection technique is used for evaluations of the visual characteristics due to the presence of defects, insects attacks, decay and other deteriorations [3, 4, 6, 7, 11]. Camera can used for picture a time to reflect existing damage, taking photos of the affected areas is quite important $[7,8]$.

A good way to begin an inspection for decay is a visual inspection technique search for decay manifestations, emphasizing locations or conditions most conducive to prolonged wetting [12-15].

Decay usually results in abnormal coloration of the wood. The first indication of decay is often brown streaks or blotches; purplish streaks are sometimes present. As wood approaches advanced stages of decay, it loses luster and may exhibit pronounced changes in color. Of course, judgments based on color necessitate familiarity with the appearance of 
sound wood. Sound, healthy softwood has a pleasant, fresh, resinous smell, whereas decayed wood usually has a mushroom-like, stale odor. However, a musty, moldy smell, though indicative of damage conditions favorable to decay, does not necessarily indicate the presence of decay [3].

The main pathological manifestations that can be observed by visual inspection technique are: signs of distress (collapsed, failed members, excessive deflections); missing members; fruiting bodies; sunken faces or localized surface depressions; staining or discoloration; insect activity; fungi, cracks; grade stamps; checks.

\section{The City Poços de Caldas}

Founded on November 6, 1872, Poços de Caldas is located at coordinates $21^{\circ} 47^{\prime} 10,77^{\prime \prime}$; ; 46 $33^{\prime} 47,16^{\prime \prime}$ O [Google Earth] and 1213 meters [IBGE] in the Serra da Mantiqueira, in the southern state of Minas Gerais, in Brazil. Mild climate and an average temperature of around $18^{\circ} \mathrm{C}$, with a population of approximately 140,000 inhabitants, the city has the highest life expectancy (78.2 years) in the state. It is a tourist town, known for his discovery of the hot springs, and 70 million square meters of green area spread over hundreds of parks, gardens, parks, day care they receive, and the Sierra de São Domingo, a nature reserve, tumbled the historical heritage of the state [9].

\section{Current Assessment of timber roof structures type "Hauff", in Poços de Caldas}

Nowadays we still have in use important type "Hauff" timber roof structures and its assessment is recommended.

It is knowledge of the technical and scientific timber roof structural systems type "Hauff" played a role of great importance in the history of Brazilian construction industry, primarily with timber structures. In Poços de Caldas has been observed that various timber roof structural systems had such great acceptance between the 1940s and 1960s, and today was identified 12 buildings with these structures still exist. The covers were called here by RTH (Roof Type Hauff).

However, in assessment of some roofs structural systems identified, were observed by visual inspection technique, pathological manifestations of: moisture migration from tiles, staining or discoloration; signs of stain fungi; signs of distress with excessive deflections of purlins; missing members; irregular maintenance; among others.

\section{Results and Discussion}

\section{Roof RTH-01: Hangar of the Aero Club of Poços de Caldas}

The first building of Poços de Caldas city, more known in the scientific-technical, for its beautiful timber roof structure lamellar type (Figure 1), with approximately 25 meters of free span, is the hangar Aero Club of Poços de Caldas. This building is located in the approximate coordinates of GPS $21^{\circ} 50^{\prime}$ 18,42”S; 46 33' 46,56”O; altitude of 1261 meters [Google Earth]. With donations from members, beginning in 1943 the construction of the hangar in Aero Club of Poços de Caldas, [10].

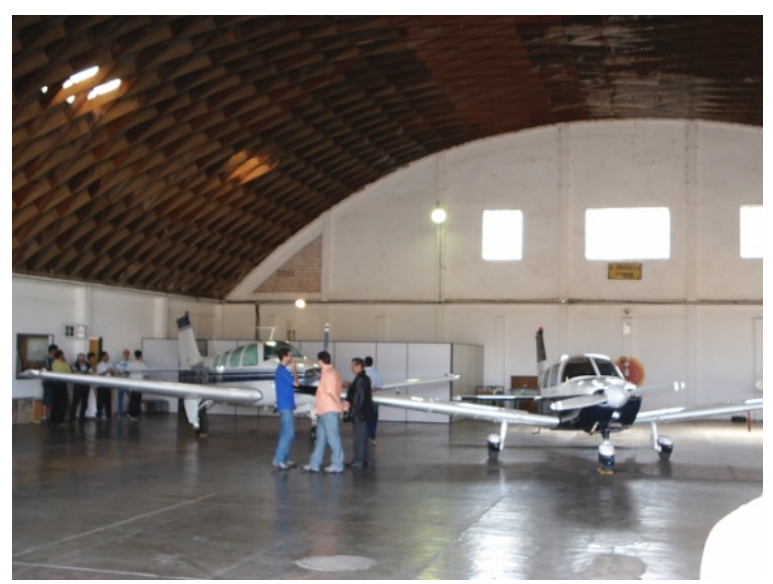

(a)

Inside view of the hangar.

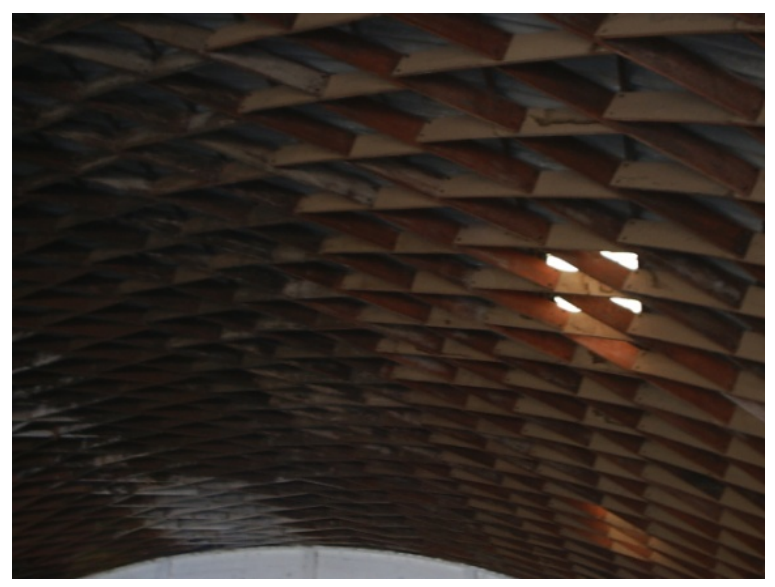

(b)

Details of lamellar roof: moisture migration from tiles.

Figure 1. Details of the structural system of the lamellar timber roof structure

\section{Roofs RTH-02 RTH-03 RTH-04 RTH-05}

The second building identified in Poços de Caldas, also known in the scientific-technical, whose architectural design is subdivided into four independents areas of warehouses with timber roof structural systems medium to large spans: RTH-02 (Figure 2a); RTH-03 (Figure 2b); RTH-04 (Figure 3a); RTH-05 (Figure 3b). The main roof, these sheds, is situated on approximate coordinates of GPS $21^{\circ} 50^{\prime} 18,42$ ”'S; $46^{\circ} 33$ ' 46,56”'O, and altitude of 1204 meters.

\section{Roofs RTH-06 RTH-07}

The roof here identified by RTH-06 (Figure 4a) known in the scientific-technical, has structural system type plywood arch, with approximately 20 meters of span. This roof is situated on GPS coordinates $21^{\circ} 47^{\prime} 29,10^{\prime \prime} S$; $46^{\circ} 33^{\prime}$ 48,19”O; and altitude of 1204 meters, [Google Earth].

The roof here identified by RTH-07 (Figure 4b) known in the scientific-technical, also has structural system type Plywood arch, with approximately 40 meters of span. This roof is situated on the GPS coordinates $21^{\circ} 47^{\prime} 05,90^{\prime \prime}$; $46^{\circ}$ 33' 50,05”O; and altitude of 1204 meters, [Google Earth]. However it was not possible to photograph details of these 
roofs, because they were coated with PVC lining. Therefore, it was observed that the wood pieces were paintings with enamel in green, and the structural elements presented in excellent condition, including metal rods.

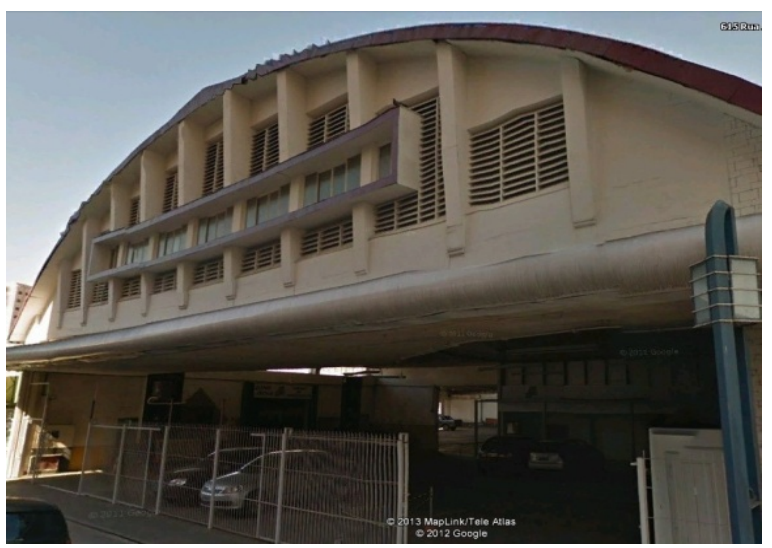

(a)

Roof RTH-02: Plywood arch 30 m of span.

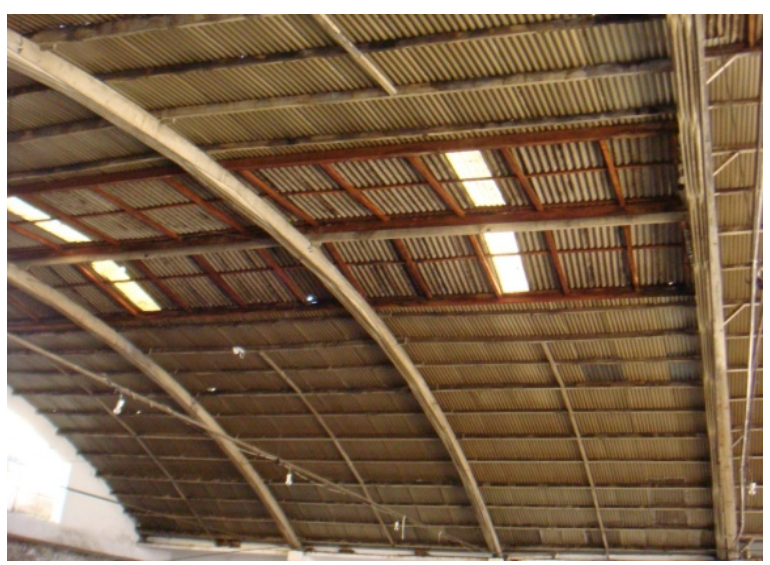

(b)

Roof RTH-03: Vertical sawn lumber nailed arch $30 \mathrm{~m}$.

Figure 2. Timber roof structural systems: Roof RTH-02; RTH-03 [11]. Photos: Authors

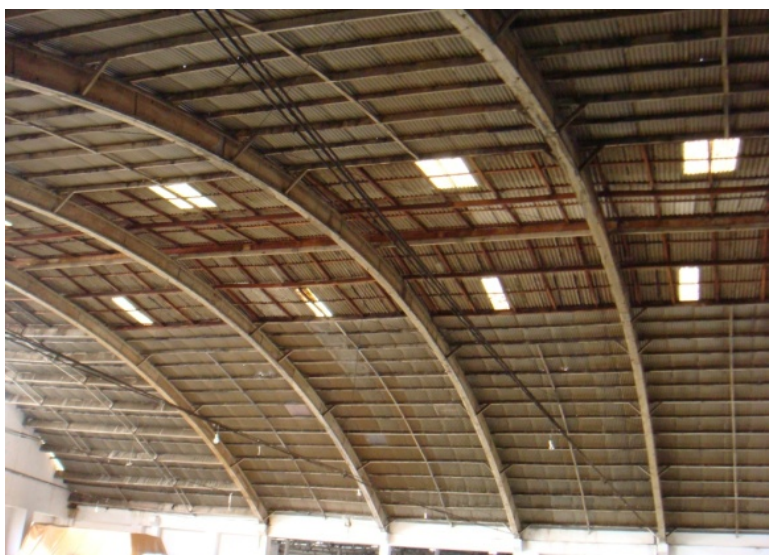

(a)

Roof RTH-04: Plywood arch $45 \mathrm{~m}$ of span.

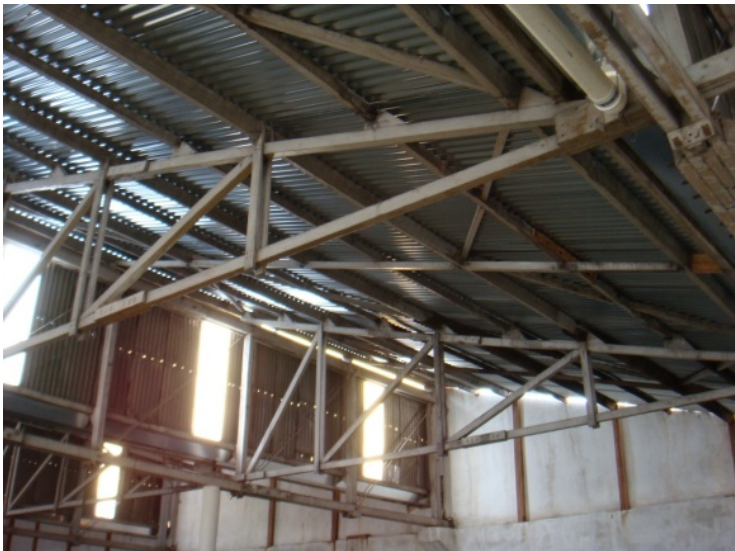

(b)

Roof RTH-05: Shed truss roof $20 \mathrm{~m}$.

Figure 3. Timber roof structural systems: Roofs RTH-04; RTH-05 [11]. Photos: Authors

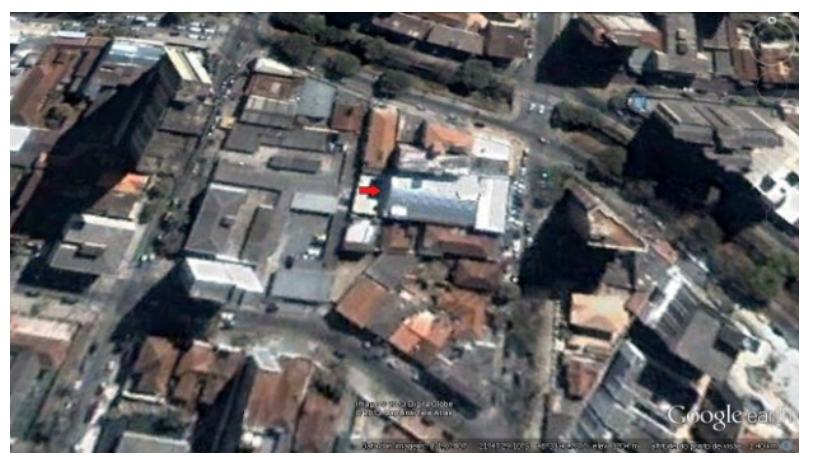

(a)

RTH-06: Plywood arch 20m of span.

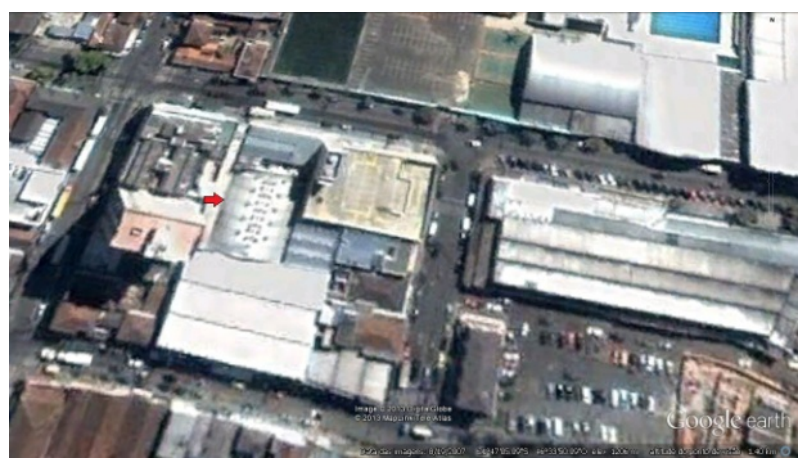

(b)

RTH-07: Plywood arch 40m of span.

Figure 4. Aerial view of rooftops: RTH-06; RTH7. Source: [Google Earth]

\section{Roof RTH-08}

The roof RTH-08 (Figure 5) has structural system type sawn lumber nailed arch, with approximately 15 meters of span. But it was also not possible to photograph details of this roof. This roof is situated on the GPS coordinates $21^{\circ} 47^{\prime}$ 13,10"S; 46 33' 40,75”O; and altitude of 1216 meters. The leasing plan of this building is in $\mathrm{L}$. 


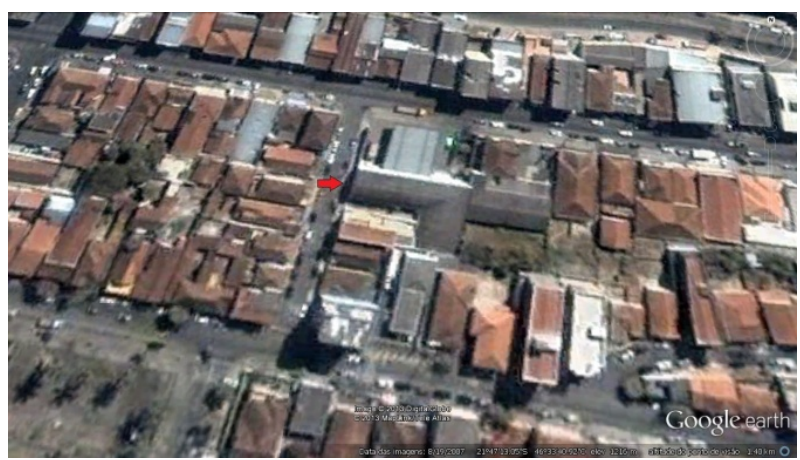

(a)

Aerial view of rooftops L.

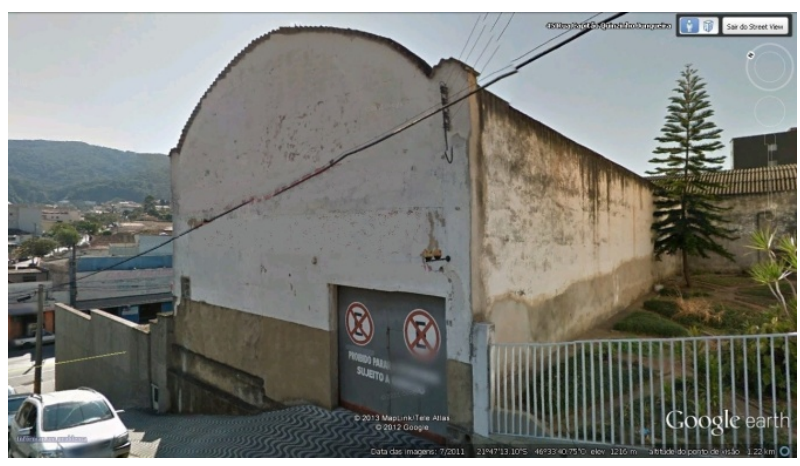

(b)

Warehouse: RTH-08.

Figure 5. Warehouse with timber roof structural system: RTH-09. Source: [Google Earth]

\section{Roof RTH-09}

The roof RTH-09 (Figure 6) has structural system type plywood arch, with approximately 22 meters of span. That is situated on GPS coordinates $21^{\circ} 47^{\prime} 33,20^{\prime \prime} \mathrm{S} ; 46^{\circ} 33^{\prime}$ 48,85 ” O; and altitude of 1207 meters. The wooden parts of this structure were with enamel paintings in gray, and the structural elements and metal rods, had good repair. It is probable that the wood is Peroba Rosa, because pink staining of purlins.

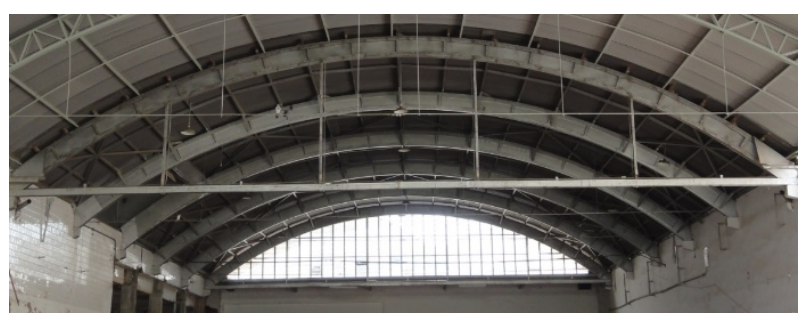

Figure 6. Roof RTH-09: Structural system type plywood arch 22m of span

\section{Roofs RTH-10 e RTH-11}

The roof RTH-10 is located at GPS coordinates $21^{\circ} 47^{\prime}$ 33,09”S; 46 33' 52,41”O; and altitude of 1210 meters. The roof RTH-11 is located in the GPS coordinates $21^{\circ} 47^{\prime}$ 32,58”S; $46^{\circ} 33^{\prime}$ 52,31'O; and altitude of 1209 meters. The buildings of these roofs corresponds to 2 warehouses germinated (Figure 7a). The roof RTH-10 has structural system type plywood arch, with approximately 16 meters of span, and with skylight central projection of natural light (Figure 7b). The wooden parts of the roof RTH-10 were with enamel paintings in gray, and the structural elements and metal rods, presented in excellent condition.

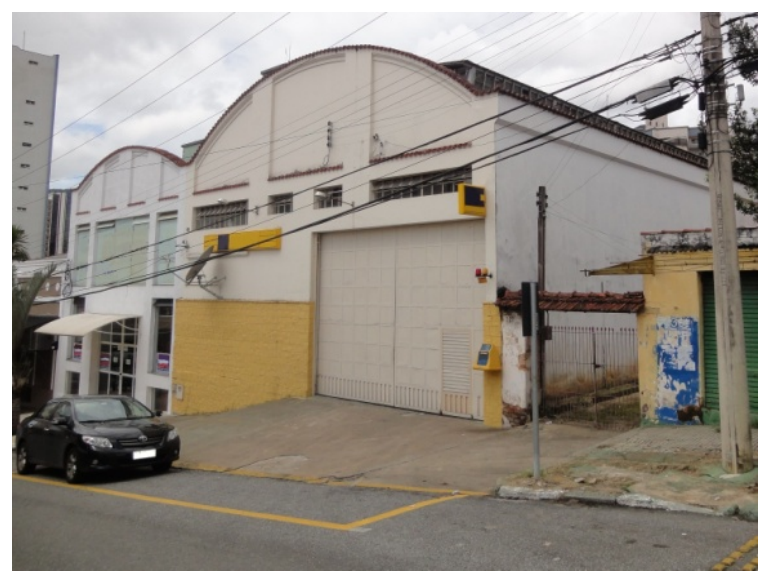

(a)

Warehouses germinated: RTH-10 e RTH-11.

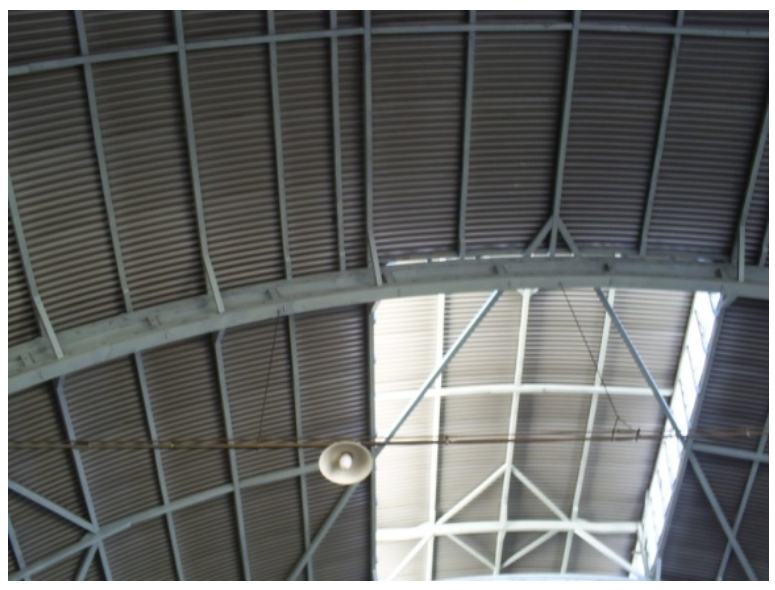

(b)

Plywood arch structural system $\sim 16 \mathrm{~m}$ with skylight.

Figure 7. Warehouses (RTH-10 e RTH-11) with timber roof structural systems

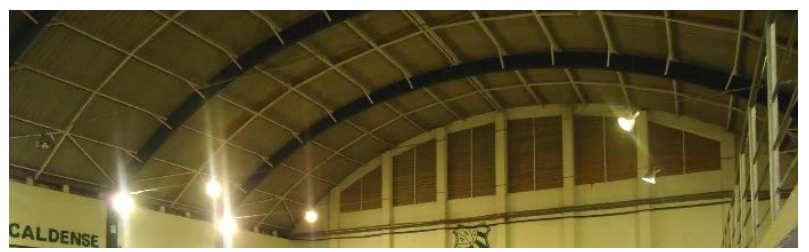

Figure 8. Roof RTH-12: Structural system type plywood arch $\sim 30 \mathrm{~m}$

The roof RTH-11 is a dual-waters, with approximately 12 meters of span, also have skylight central to projection for natural lighting. However, it was not possible to photograph the internal area of the roof.

\section{Roof RTH-12: Roof of the Gymnasium of the club “Associação Atlética Caldense"}

The roof RTH-12 (Figure 8) of Gymnasium of the Club's "Caldense Athletic Association" has roof structural system type plywood arch, with approximately 30 meters span. This roof is situated on the GPS coordinates $21^{\circ} 47^{\prime} 06,30$ ”' $\mathrm{S} ; 46^{\circ}$ 
33' 45,05”O; and altitude of 1208 meters. The wooden parts of the roof RTH-12 are structural system type plywood arch, with metal rods, and were in enamel paints green.

\section{Conclusions}

Throughout its existence, "Hauff" played a highly relevant role in the history of civil engineering in Brazil, but particularly during the period of its greatest production, which corresponded to its wood structures phase. "Hauff" can be considered a company that introduced wood structure technologies in the country and which was in large part responsible for training artisans linked to the production of timber structures, master carpenters, draftsmen and designers, and for enriching the body of technical knowledge if many engineers who participated in this production. From the example of "Hauff", according to the demand with the growth of construction in the country, have emerged in the market other manufacturers of timber structures for roofing, which was to highlight the criteria that they have achieved in the domestic market, but also the structural types offered by them. During techniques visits, in assessment of some of these roofs identified, it was possible to detect, by visual inspection technique, pathological manifestations in various structural elements of the timber roofs, which could be avoided with regular inspections and preventive maintenance. There is a lack of preventative maintenance and control of timber roof structures in Brazil. In this way the assessment, maintenance and rehabilitation of timber structures must be an important subject for the future of timber structures in Brazil. The routine sequential for recommendation at the inspection process of the timber roofs structures, can used: the visual inspection technique, with records photos; the sounding technique with hammer; the probing test; the pick test with mortise chisel; the moisture meter; the microdrilling with resistograph; among others tests.

\section{ACKNOWLEDGMENTS}

The authors thank the National Counsel of Technological and Scientific Development (CNPq) for its financial backing of this work.

\section{REFERENCES}

[1] Cóias, V. Qualificação dos profissionais e das empresas para a qualidade na reabilitação de estruturas de madeira. CIMAD $11-1^{\circ}$ Congresso Ibero - Latino Americano da Madeira na Construção. Coimbra, Portugal, 2011.

[2] César, S. F. As estruturas Hauff de Madeira no Brasil.
(Master’s Dissertation, Escola de Engenharia de São Carlos, USP. Orientador: Prof. Dr. Carlito Calil Junior. São Carlos, 1991.

[3] Highley, T. L.; Scheffer, T. Controlling decay in waterfront structures. Evaluation, Prevention, and Remedial Treatments. Department of Agriculture, Forest Service, Forest Products Laboratory. FPL-RP-494. Madison, WI, USA, 1989.

[4] Ritter, M. A.; Morrell, J. J. Timber bridges. Department of Forest Products, Oregon State University, 1990.

[5] Calil Jr., Carlito; Brito, L. D. Manual de Projeto e Construção de Estruturas com Peças Roliças de Madeira de Reflorestamento. Departamento de Engenharia de Estruturas, Escola de Engenharia de São Carlos, Universidade de São Paulo. ISBN: 978-85-8023-000-0. Editora EESC. São Carlos, 2010.

[6] Pellerin, Roy F.; Ross, J. 2002. Nondestructive Evaluation of Wood. Forest Products Society, Madison, WI, USA, 2002.

[7] Arriaga, F.; Pezaza, F.; Esteban, M.; Bobadilla, I.; Garcia, F. Intervención en estructuras de madera. ISBN 84-87381-24-3. AITIM, Madrid, 2002.

[8] Brito; L. D.; Calil Jr., C. Evaluation by visual inspection technique of "Hauff Type" timber roof structure at "São Carlos Clube” Gymnasium in Brazil. ICDS12 - International Conference Durable structures: from construction to rehabilitation. Lisbon, Portugal, 2012.

[9] Puc Minas. História da cidade de Poços de Caldas. Disponível e m: $<<<$ http://www.pucpcaldas.br/home.php?pagina=cidade _historia.php $>>>$ [Date accessed: 01/22/2013].

[10] Aeroclube de Poços de Caldas 1945. Homenagem do Aero Clube de Poços de Caldas ao pai de aviação Santos Dumont. Jornal Aero Clube de Poços de Caldas. Poços de Caldas.

[11] Brito, L. D. 2014. Patologia em estruturas de madeira: metodologia de inspeção e técnicas de reabilitação. Tese (Doutorado) Departamento de Engenharia de Estruturas, Escola de Engenharia de São Carlos, Universidade de São Paulo. São Carlos, Brasil, 2014.

[12] Christoforo, A. L.; Panzera, T. H.; Silva, L. J.; Araujo, V. A.; Silva, D. A. L.; Rocco, F. A. L. Evaluation of the Modulus of Elasticity in Damaged Wooden Beams. International Journal of Materials Engineering, v. 5, p. 92-97, 2015.

[13] Monteiro, V. F.; Bacarji, E.; Gomes, O. F.; Lahr, F. A. R.; Christoforo, A. L. Theoretical and Experimental Studies of Timber Composite Beams Reinforced by Cold Formed Steel Sheets. International Journal of Materials Engineering, v. 5, p. 50-63, 2015.

[14] Calil Jr., C.; Christoforo, A. L. Manual of Design and Construction of Timber Bridges. 1. ed. SaarbrükenDeutschland/Germany: Lambert Academic Publishing (LAP), v. 1. 291p., 2015.

[15] Pinheiro, R. V.; Lazaro, L. G. F.; Macedo, L. B.; Christoforo, A. L.; Lahr, F. A. R. Repair Methods Indication for a Timber Coverage Structure Located in Sinop City - Brazil. International Journal of Materials Engineering, v. 6, p. 39-46, 2016. 